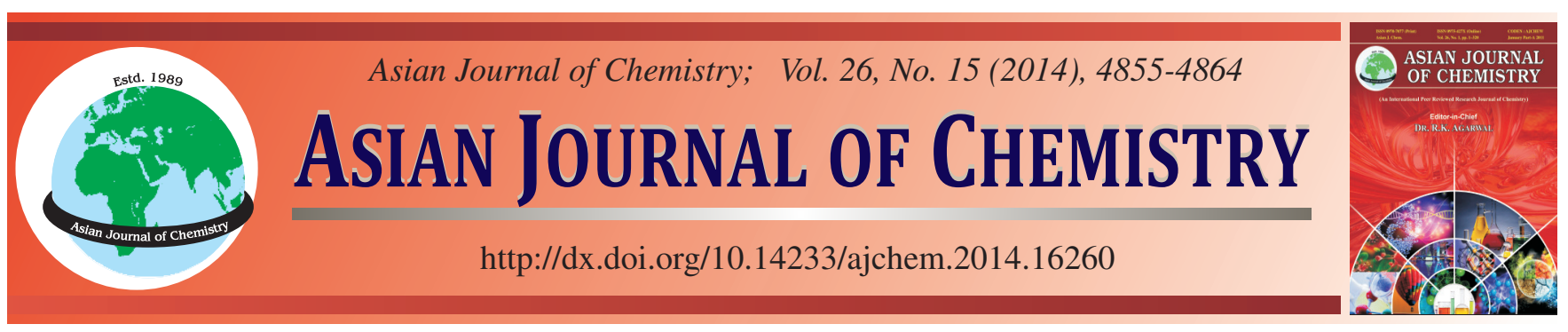

\title{
Pristine, Chromogenic Polyaniline - A Novel Sorbent for Ion Exchange of Sodium Salts in Aqueous Solution
}

\author{
N.A. Deepa, C. Dhivya, S. Anbu Anjugam Vandarkuzhali, R. Santhi and N. Radha*
}

Post Graduate and Research Department of Chemistry, Seethalakshmi Ramaswami College, Tiruchirappalli-620 002, India

*Corresponding author: E-mail: radha.chem1955src@gmail.com

Received: 30 August 2013;

Accepted: 7 January 2014;

Published online: 16 July 2014;

AJC-15586

The sorption characteristics and ion exchange behaviour of polyaniline picrate (PANIPI) with various sodium salts $(\mathrm{NaF}, \mathrm{NaCl}, \mathrm{NaBr}$, $\mathrm{NaNO}_{2}, \mathrm{NaNO}_{3}, \mathrm{NaClO}_{4}, \mathrm{Na}_{2} \mathrm{SO}_{4}, \mathrm{NaH}_{2} \mathrm{PO}_{4}, \mathrm{NaOH}, \mathrm{Na}_{2} \mathrm{CO}_{3}$ and $\mathrm{NaHCO}_{3}$ ) have been studied. Langmuir, Freundlich, Temkin and RedlichPeterson isotherm models are tested to describe the equilibrium established between PANIPI resin and solutions of sodium salt. The correlation coefficients show that Langmuir, Freundlich and Temkin models fit well for this sorption process. The sorption constants and negative $\Delta \mathrm{G}^{\circ}$ values indicate that the sorption of sodium salts on PANIPI is a favourable process. The ion exchange capacity (IEC) of the pristine PANIPI with these salts lie in the range of $1.96-3.49 \mathrm{meq} / \mathrm{g}$ and the separation factor $(\alpha)$ vary between $0.71-3.88$ for the sodium salts used in the present study. These parameters indicate the suitability of PANIPI as a good ion exchanger. The UV-visible and FT-IR spectral changes before and after sorption are analysed to explain the sorption mechanism. The sorption capacities determined from the batch experiments are in the range 80-100 \% for the sodium salts. The regenerative ability of PANIPI resin is ascertained from the column experiments conducted in three cycles. PANIPI is also found to possess antibacterial and antifungal activities. Hence, this novel chromogenic PANIPI resin has potential applications in desalination and ion detection processes.

Keywords: Chromogenic polyaniline, Sodium salts, Sorption isotherms, Sorption capacity, Antimicrobial activity.

\section{INTRODUCTION}

Sea water has strong salinity due to its high salt content. Sea water consists of predominant quantities of sodium chloride and minor amounts of potassium, calcium and magnesium salts. It may also contain traces of water soluble organic materials and microbial components due to the entry of river water streams, flora and fauna in the oceans. Potable drinking water is necessary for good health ${ }^{1}$. Water devoid of salts are needed for laboratory and industrial use. Hence desalination and removal of ions from water bodies is important and essential. Desalination and water softening involves removal of ions by several techniques such as liquid-liquid extraction, coprecipitation, ion exchange, adsorption and reverse osmosis. In recent days, ion exchange $e^{2}$ is widely used as a cost effective sorption process.

An ion exchanging solid consists of a polymer or a material of high molecular weight which is insoluble in solvents used for ion exchange. Adsorption and ion exchange can be grouped together as sorption for a unified treatment for practical applications. The first step in interpreting any adsorption data for predicting the performance of a given adsorbent is to test the equilibrium distribution of solute between solid and liquid phases. Several PANI salts and composites are used as adsorbents for heavy metal ions ${ }^{3-6}$ and dye removal ${ }^{7-10}$. They are also used as ion-exchangers for cations ${ }^{11}$ and anions ${ }^{12,13}$ in aqueous solutions. Considerable attention has been devoted to the adsorption process, enhancing sorption capacity by suitable chemical modification of polyaniline (PANI) due to its low cost, easy synthesis, environmental stability and good processibility. Sorption studies on PANI doped with picric acid is one such step in this direction. The main focus of this study is to understand the sorption characteristics of sodium salts on PANI matrix, carrying the chromogenic picrate ion. When a sodium salt $(\mathrm{NaX})$ is in contact with polyaniline picrate (PANIPI), an equilibrium is set up between ions in solution phase and resin phase. It is expected that the salts will displace the picrate ion which has a strong $\pi-\pi^{*}$ absorption at $360 \mathrm{~nm}$. The intensity of this peak is not affected by the presence of organic species in the water. Hence the optical density at this wavelength will give a quantitative estimate of the concentration changes of ions after adsorption on PANIPI resin.

PANI normally exists in the stable emeraldine forms in solutions (Scheme-I). The presence of salts can produce different doping levels. Depending upon the $\mathrm{pH}$ of the medium PANI can exist as emeraldine base (EB) or emeraldine salt (ES) 


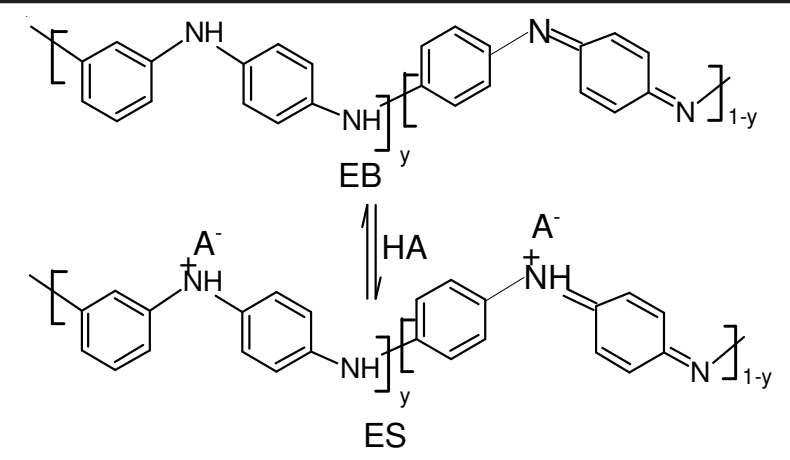

Scheme-I: Different forms of PANI

forms. The study of this adsorption process on PANIPI may reveal the intricacies of the structural changes taking place on the PANI resin.

\section{EXPERIMENTAL}

All the chemicals and reagents used were of analytical grade. Double distilled water was employed for all the experiments. Ultrasonic cleaning bath $(50 \mathrm{KHz}$, Ultrasonic Ney), UV-Visible spectrophotometer (Lambda 25, Perkin Elmer), FT-IR Spectrometer (RXI-Perkin Elmer), Electronic balance (Denver), Scanning Electron Microscope (SEM) (JEOL JSM5610LV), particle size analyser (Bluewave Microtrac Flex 10.5.4), Digital pH meter (EQ 160, Equiptronics) and Flame photometer (Elico $360 \mathrm{~A}$ ) were used for the present study.

Synthesis of sorbent-polyaniline picrate (PANIPI): An aqueous solution of ammonium peroxydisulphate $(0.1 \mathrm{M})$ was added dropwise to a stirred solution of aniline $(0.1 \mathrm{M})$ and aqueous picric acid $(0.05 \mathrm{M})$ at ambient temperature and magnetically stirred for $2 \mathrm{~h}$ to ensure completion of the reaction. The colour of the solution changed from yellow, purple, blue and green in the end. The precipitated green emeraldine salt [Scheme-II, ES1] was filtered and washed repeatedly with distilled water. Traces of unreacted oligomers were removed by repeated washing with ethanol and acetone. The green powder obtained was ultrasonically stirred in diethyl ether and hexane until a free flowing powder was obtained. The doped pristine polymer $^{14}$ was filtered and dried under dynamic vacuum at $40{ }^{\circ} \mathrm{C}$ for $24 \mathrm{~h}$. The polymers were kept in airtight containers for further characterization and adsorption studies.

Preparation of sorbate solutions: All the sodium salts were weighed accurately in an electronic balance in decimolar quantities and stock solutions were prepared in double distilled water and suitably diluted to required concentrations (2 M, $\left.10^{-1}-10^{-8} \mathrm{M}\right)$.

Spectral characterisation: The UV-visible absorption spectra were recorded in DMF, DMSO and water. The FT-IR spectra of PANIPI and PANI-sodium salts were recorded as $\mathrm{KBr}$ pellets in the range $4000-400 \mathrm{~cm}^{-1}$ to understand the structural changes taking place after adsorption. SEM and particle size analysis were used to determine the size and structural morphology of PANIPI.

Batch experiments: Sorption studies were carried out by the batch technique at $30 \pm 1{ }^{\circ} \mathrm{C}$ to obtain equilibrium data for isothermal models in their natural $\mathrm{pH}$ without any adjustment. The batch experiments were carried out by mixing preweighed amount (w) of $1 \mathrm{mg}$ of PANIPI with $25 \mathrm{~mL}(\mathrm{~V})$ of a given initial concentration of salt solutions $\left(10^{-1}-10^{-8} \mathrm{M}\right)$ in a $50 \mathrm{~mL}$ conical flask and stirred ultrasonically for $0.5 \mathrm{~h}$. At the end of the pre-determined time interval, the slurry was centrifuged and the concentration of picrate ion released $\left(\mathrm{C}_{e}\right)$ was ascertained from calibration curves at $360 \mathrm{~nm}$. The concentration of picrate ion released $\left(\mathrm{C}_{0}\right)$ in water was considered as the standard. The data obtained from the above experiments were used to construct the sorption isotherms and $\mathrm{q}_{\mathrm{m}}$ values are correlated with anionic radii.

The sorption experiments were also conducted with high concentrations $(2 \mathrm{M})$ of sodium salts by adding $10 \mathrm{mg}$ of PANIPI to $25 \mathrm{~mL}$ of the sodium salt solutions. The sorption process was monitored by following the $\mathrm{pH}$ changes at regular time intervals. The midpoints of the $\mathrm{pH}$ curves were taken for determining the $\mathrm{K}_{\mathrm{PI}^{-}}^{\mathrm{X}^{-}}$values.

Flame photometric analyses were performed on the solutions of sodium salts after the sorption experiments. From the concentration of ions present before and after the sorption process $\alpha$ values were determined.

Column experiments for desorption studies: PANIPI $(1 \mathrm{~g})$ was packed as a dry powder in a column of $1 \mathrm{~cm}$ diameter and $30 \mathrm{~cm}$ length. Sodium carbonate $(0.1 \mathrm{M}, 25 \mathrm{~mL})$ was passed through the packed bed sorbent. The eluate was collected in $2 \mathrm{~mL}$ aliquots and the elution curves were drawn by plotting changes in optical density with the volume fractions of eluate.

Antibacterial and antifungal activities of PANIPI: The antibacterial and antifungal activities of the synthesized PANIPI were carried out using agar well diffusion method ${ }^{15}$ against various Gram-positive and Gram-negative bacteria and fungus Candida albicans. The bacterial cultures were obtained from the microbial type culture collection and gene bank (MTCC), Institute for Microbial Technology, Chandigarh, India. For antibacterial studies, nutrient agar medium was prepared by using peptone $(5 \mathrm{~g})$, beef extract (1.5 g), yeast extract (1.5 g) and $\mathrm{NaCl}(5 \mathrm{~g})$ in $1000 \mathrm{~mL}$ distilled water and the $\mathrm{pH}$ was adjusted to 7 and agar $(20 \mathrm{~g})$ was added to the solution. Potato dextrose agar was used for the antifungal studies. The agar media were sterilized in aliquots of $15 \mathrm{~mL}$ at a pressure of 15 lbs for $15 \mathrm{~min}$. The nutrient agar media were transferred into sterilized petri dishes in a laminar air flow unit. After solidification of the media, the strains were swabbed on the petri plates which has agar as the nutrient source. The plates were

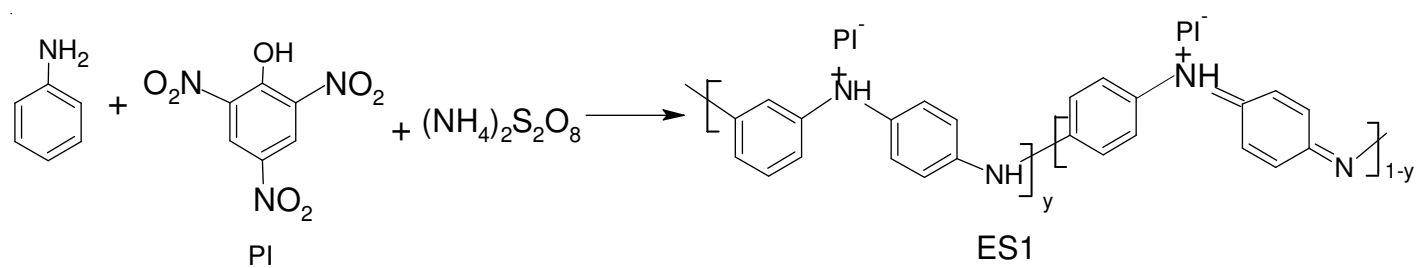

Scheme-II: Chemical oxidative polymerization 
punctured as four wells in each petri dish with the help of a sterile cork borer. To this plate, one drop of respective dilution of PANIPI in DMSO $(25,5075,100 \mu \mathrm{g} / \mathrm{mL})$ was added using micropipette and incubated for $48 \mathrm{~h}$ at $37^{\circ} \mathrm{C}$ in the incubation chamber. Average zone diameters were measured using Intech antibiotic zone reader (model IN-1215, India). All the experiments were done thrice and average readings were considered.

\section{RESULTS AND DISCUSSION}

The present study has been carried out to show how the anion selectivity, influence the picrate-anion exchange equilibrium on PANIPI resin and to propose a suitable exchange mechanism. The presence of chromogenic picrate ion on PANI matrix makes the sorption study to be performed easily, since the expelled picrate ion concentration can be monitored by measuring the optical density at $360 \mathrm{~nm}$.

Structural characterization of sorbent: Characterization of the sorbent, PANIPI is carried out by UV-visible, FT-IR, SEM and particle size analyzer.

UV-visible spectral analysis: In the UV-visible spectrum of PANIPI in DMF (Fig. 1a) two peaks are observed at 360 $\mathrm{nm}$ and $621 \mathrm{~nm}$ which are characteristic of the benzenoid and quinoid ${ }^{16,17}$ moieties in the PANI skeleton. The picrate ion peak has merged with the intense $\pi-\pi^{*}$ benzenoid peak. In DMSO besides these peaks a free electron absorption tail ${ }^{18}$ is observed in the region of $800-1100 \mathrm{~nm}$ indicative of ES1 structure (Scheme-II).
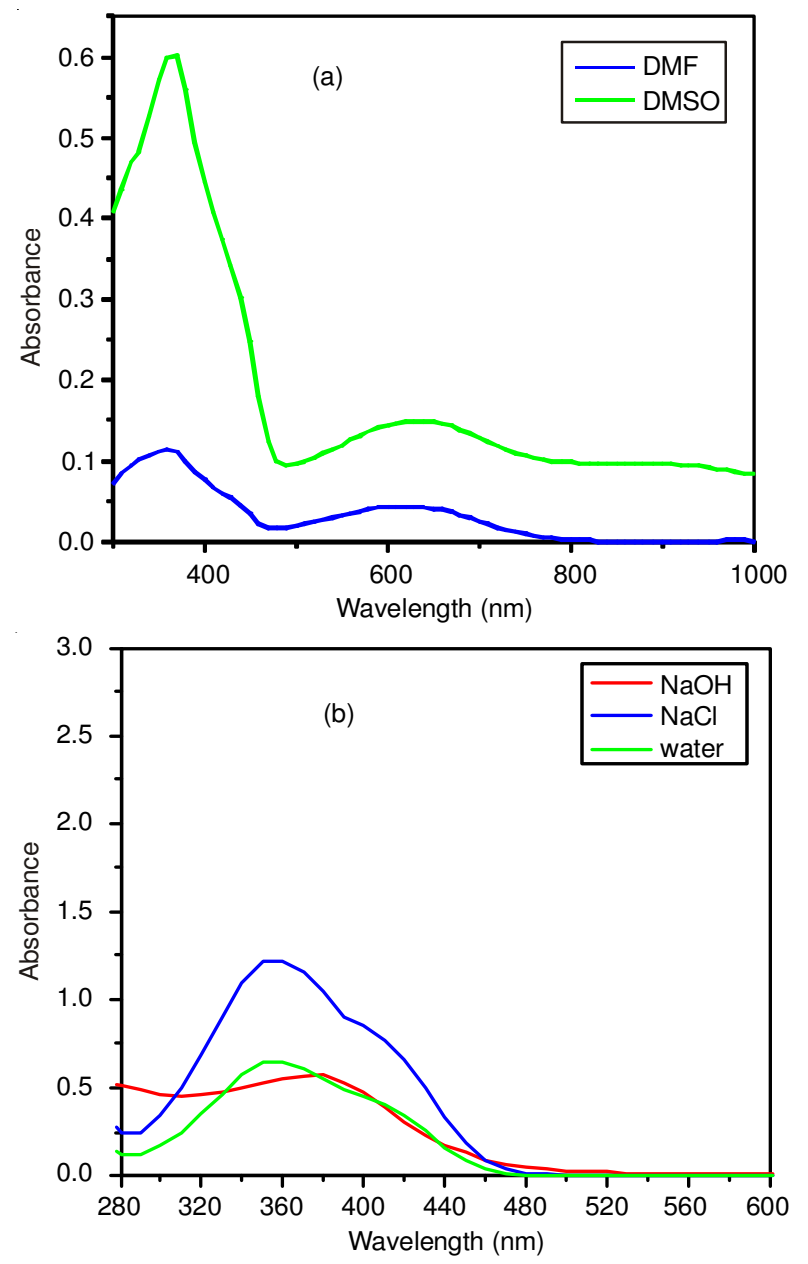

Fig. 1. UV-visible spectra of PANIPI before (a) and after (b) exchange
FT-IR spectral analysis: In the FT-IR spectra of PANIPI, absorptions at $3425,3246 \mathrm{~cm}^{-1}$ correspond to N-H stretching vibrations while the $\mathrm{C}-\mathrm{H}$ stretching vibrations are observed at $3080,2984,2847$ and $2827 \mathrm{~cm}^{-1}$. Peaks in the region 3400$2800 \mathrm{~cm}^{-1}$ which are partly masked by the extended absorption tail of the protonated PANI ${ }^{19}$ correspond to ES1 structure. The stretching vibrations at 1588 and $1491 \mathrm{~cm}^{-1}$ are assigned to quinoid $(\mathrm{N}=\mathrm{Q}=\mathrm{N})$ and benzenoid $(\mathrm{N}=\mathrm{B}=\mathrm{N})$ moieties. At 1300 $\mathrm{cm}^{-1}$ the $\mathrm{C}-\mathrm{N}$ and $\mathrm{NO}_{2}$ stretching vibrations are merged (Table1). The absorption at $1137 \mathrm{~cm}^{-1}$ is due to charge delocalistion on the polymer backbone ${ }^{20}$. The bending vibrations are observed as three distinct bands at 797, 699 and $504 \mathrm{~cm}^{-1}$.

Structural morphology: The SEM micrograph of PANIPI (Fig. 2) shows aggregation ${ }^{21}$ along with a granular morphology and clearly depicts the presence of chromogenic species i.e. picrate outside the PANI skeleton giving PANIPI the amphiphilic nature similar to micelles. PANI resin in the EB form has been reported to be a hydrophobic amorphous powder ${ }^{22}$. On the other hand, in the present work picrate ion in PANIPI renders crystallinity and hydrophilicity to the PANI resin. The particle size analysis of PANIPI reveals that the particles are of 4.02 to $6.28 \mu \mathrm{m}$ in diameter. This small size provides large surface area for enhanced sorption capacity.

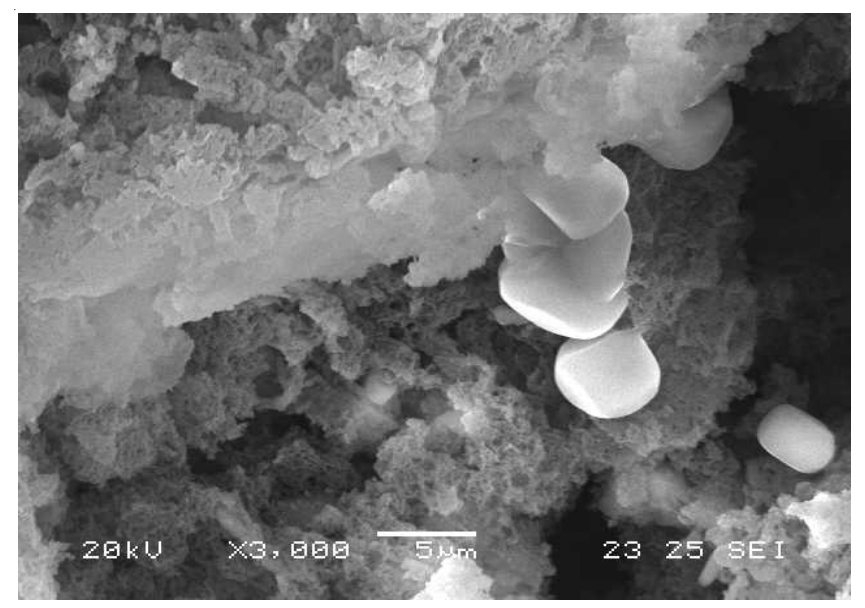

Fig. 2. SEM micrograph of PANIPI

Sorption isotherms: When PANIPI is equilibrated with sodium salts of different concentrations, ion exchange occurs readily with the picrate ion and it is observed that both sorption and desorption process (Scheme-IIIa) are facilitated on the PANIPI resin.

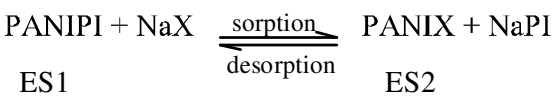

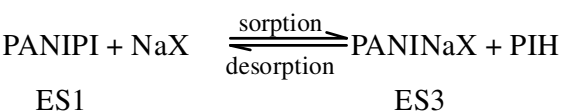

$$
\begin{aligned}
& \text { PANIPI + NaX } \underset{\text { desorption }}{\stackrel{\text { sorption }}{\rightleftharpoons}} \text { PANI + PIH + picrate complexes }
\end{aligned}
$$

Scheme-III: Equilibrium between PANIPI and sodium salts; (a) $10^{-1}-10^{-8}$ $\mathrm{M}, \mathrm{pH}=7-8$; (b) $2 \mathrm{M}, \mathrm{pH}=3$; (c) $2 \mathrm{M}$ bases, $\mathrm{pH}=8-13$ 


\begin{tabular}{|c|c|c|c|c|c|c|c|c|c|c|}
\hline & & FT-IR SP & CTRAL DATA & EFORE A & $\begin{array}{l}\text { BLE-1 } \\
\text { D AFTER }\end{array}$ & EXCHANGE & F PANIPI RI & & & \\
\hline $\begin{array}{l}\text { Vibrational } \\
\text { assignment }\end{array}$ & $\mathrm{N}-\mathrm{H}$ str & $\begin{array}{c}\mathrm{Ar} \mathrm{C}-\mathrm{H} \text { str/ } \\
\mathrm{NH}_{2}^{+}\end{array}$ & $\mathrm{C}=\mathrm{N}^{+}$ & $\mathrm{N}=\mathrm{Q}=\mathrm{N}$ & $\mathrm{N}=\mathrm{B}=\mathrm{N}$ & $\mathrm{CN}$ str & $\begin{array}{l}\text { Ar C-N-C } \\
\text { bending }\end{array}$ & $\begin{array}{c}\mathrm{C}-\mathrm{H} \\
\text { bending }\end{array}$ & $\begin{array}{l}\text { C-C ring } \\
\text { deforma } \\
\text { tion }\end{array}$ & $\begin{array}{l}\mathrm{C}-\mathrm{N}-\mathrm{C} \\
\text { torsion }\end{array}$ \\
\hline $\begin{array}{l}\text { Pristine } \\
\text { PANIPI }\end{array}$ & $\begin{array}{l}3425 \\
3246\end{array}$ & $\begin{array}{l}3080,2984, \\
28472827\end{array}$ & $2800-2400$ & 1588 & 1491 & $\begin{array}{l}1300, \mathrm{~s} \\
\left(\mathrm{NO}_{2}\right)\end{array}$ & 1137 & 797 & 699 & 504 \\
\hline $\mathrm{NaF}$ & $\begin{array}{l}3443 \\
3252\end{array}$ & $2900-2826$ & 2242 & 1599 & 1501 & $\begin{array}{l}1345(F) \\
1310\end{array}$ & 1145 & 818 & 708 & 508 \\
\hline $\mathrm{NaCl}$ & $\begin{array}{l}3409 \\
3225\end{array}$ & $\begin{array}{l}3010-2951 \\
2900\end{array}$ & $2400-2000$ & 1585 & 1495 & 1303 & 1141 & 804 & 703 & $\begin{array}{l}590(\mathrm{Cl}) \\
505\end{array}$ \\
\hline $\mathrm{NaBr}$ & $\begin{array}{l}3598 \\
3418 \\
3213\end{array}$ & $\begin{array}{l}30862972 \\
2900\end{array}$ & $2400-2000$ & 1577 & 1495 & 1296 & 1142 & 805 & 703 & $\begin{array}{l}585(\mathrm{Br}) \\
496\end{array}$ \\
\hline $\mathrm{NaNO}_{2}$ & $\begin{array}{l}3442 \\
3250\end{array}$ & $2900-2828$ & $2600-2010$ & 1593 & 1494 & $\begin{array}{l}1380\left(\mathrm{NO}_{2}\right) \\
1266\end{array}$ & 1146 & 789 & 702 & 510 \\
\hline $\mathrm{NaNO}_{3}$ & $\begin{array}{l}3439 \\
3240\end{array}$ & 29262821 & 23642197 & 1595 & 1485 & $\begin{array}{l}13831352 \\
\left(\mathrm{NO}_{3}\right) 1295\end{array}$ & 1119 & 783 & 696 & 500 \\
\hline $\mathrm{NaClO}_{4}$ & $\begin{array}{l}3436 \\
3230\end{array}$ & $\begin{array}{l}30102920- \\
2900\end{array}$ & 2356 & 1587 & 1485 & 1289 & $\begin{array}{l}1100 \\
1083\left(\mathrm{ClO}_{4}\right)\end{array}$ & 789 & $\begin{array}{l}696 \\
615\end{array}$ & 498 \\
\hline $\mathrm{Na}_{2} \mathrm{SO}_{4}$ & $\begin{array}{l}3440 \\
3248\end{array}$ & $\begin{array}{l}3010,2962 \\
2835\end{array}$ & $2800-2400$ & 1594 & 1496 & $1304\left(\mathrm{SO}_{4}\right)$ & 1138 & 795 & $\begin{array}{l}703 \\
617\end{array}$ & 506 \\
\hline $\mathrm{NaH}_{2} \mathrm{PO}_{4}$ & $\begin{array}{l}3426 \\
3210\end{array}$ & 28312820 & 2387 & 1593 & 1486 & 1284 & $\begin{array}{l}11401076 \\
941\left(\mathrm{PO}_{4}\right)\end{array}$ & 783 & 695 & 504 \\
\hline $\mathrm{NaOH}$ & $\begin{array}{l}3430 \\
3200 \mathrm{sh}\end{array}$ & $2821, \mathrm{sh}$ & $2197, \mathrm{w}$ & 1591 & 1497 & 1350 & 1160 & 832765 & 611 & - \\
\hline $\mathrm{Na}_{2} \mathrm{CO}_{3}$ & $\begin{array}{l}3423 \\
3200 \mathrm{sh}\end{array}$ & $\begin{array}{l}3010, \text { sh } \\
2830, \text { sh }\end{array}$ & $\begin{array}{l}2800-2400 w \\
1871, \\
w(C=O)\end{array}$ & 1592 & 1489 & 13361272 & 1159 & 839 & 695 & 508 \\
\hline $\mathrm{NaHCO}_{3}$ & $\begin{array}{l}3401 \\
3200 \mathrm{sh}\end{array}$ & $\begin{array}{l}3010, \text { sh } \\
2828, \text { sh } \\
2800, \text { sh }\end{array}$ & $\begin{array}{l}2800-2400, w \\
2020-1900, w \\
(\mathrm{C}=\mathrm{O})\end{array}$ & 1592 & 1497 & 1347 & 1158 & 829774 & 701 & 517 \\
\hline
\end{tabular}

Adsorption isotherms can be used to describe how solutes interact with adsorbents and are critical in optimizing the use of adsorbents. The sorption isotherm is the equilibrium relationship between the concentration of ions in the fluid phase and on the adsorbent at a given temperature. The isotherm is characterized by certain constants, the values of which express the surface properties and affinity of the PANIPI towards different sodium salts. The commonly used isotherms namely Langmuir, Freundlich, Temkin and Redlich-Peterson isotherms are applied for this study. For accuracy all the experiments are performed thrice and the mean of the three values were taken with an error of $2 \%$. Graphs are constructed with Origin 8.6 software and the slopes and intercepts are calculated using linear regression analysis.
Langmuir isotherm: For isothermal studies, optimized conditions are applied for all the sodium salt solutions which obeyed linearized Langmuir isotherm ${ }^{23}$ (eqn. 1), showing that the chemisorbed adsorbate layers may be one molecule thick. In the Langmuir isotherm applied for the sorption process, $\mathrm{q}_{\mathrm{m}}$ is the maximum amount adsorbed, $\mathrm{K}_{\mathrm{L}}$ is the coefficient related to affinity, $1 / \mathrm{K}_{\mathrm{L}} \mathrm{q}_{\mathrm{m}}$ is the slope and $\left(1 / \mathrm{q}_{\mathrm{m}}\right)$ is the intercept.

$$
\frac{1}{q_{e}}=\frac{1}{K_{L} q_{m} C_{e}}+\frac{1}{q_{m}}
$$

A plot of $1 / \mathrm{q}_{\mathrm{e}}$ vs. $1 / \mathrm{C}_{\mathrm{e}}$ (Fig 3a) is found to be linear over the entire concentration range studied with a good linear regression coefficient (Table-2). Further analysis of the Langmuir equation is made on the basis of separation factor $\left(\mathrm{R}_{\mathrm{L}}\right)^{24}$ expressed in eqn. 2.

TABLE-2

ISOTHERMAL PARAMETERS OF LANGMUIR AND FREUNDLICH SORPTION ISOTHERMS FOR PANIPI ADSORBENT

\begin{tabular}{|c|c|c|c|c|c|c|c|c|c|}
\hline \multirow{2}{*}{$\begin{array}{c}\text { Adsorbate } \\
\mathrm{NaX}\end{array}$} & \multicolumn{2}{|c|}{ Langmuir constants } & \multirow{2}{*}{$\mathrm{R}^{2}$} & \multirow{2}{*}{${ }^{\mathrm{a}} \mathrm{S} . \mathrm{D}$} & \multicolumn{2}{|c|}{ Freundlich constants } & \multirow{2}{*}{$\mathrm{R}^{2}$} & \multirow{2}{*}{ S.D } & \multirow{2}{*}{$\begin{array}{c}-\Delta \mathrm{G}^{\circ} \\
(\mathrm{KJ} / \mathrm{mol})\end{array}$} \\
\hline & $\mathrm{q}_{\mathrm{m}}(\mathrm{mg} / \mathrm{g})$ & $\mathrm{K}_{\mathrm{L}}(\mathrm{L} / \mathrm{mg})$ & & & $\mathrm{K}_{\mathrm{F}}(\mathrm{L} / \mathrm{mg})$ & $\mathrm{n}$ & & & \\
\hline $\mathrm{NaF}$ & 12.48 & 0.109 & 0.940 & 0.017 & 0.025 & 0.261 & 0.978 & 0.011 & 5.583 \\
\hline $\mathrm{NaCl}$ & 26.74 & 0.084 & 0.904 & 0.026 & 0.124 & 0.335 & 0.983 & 0.011 & 6.239 \\
\hline $\mathrm{NaBr}$ & 15.34 & 0.100 & 0.942 & 0.011 & 0.027 & 0.266 & 0.979 & 0.019 & 5.801 \\
\hline $\mathrm{NaNO}_{2}$ & 10.20 & 0.115 & 0.969 & 0.022 & 0.064 & 0.301 & 0.935 & 0.051 & 5.446 \\
\hline $\mathrm{NaNO}_{3}$ & 8.29 & 0.117 & 0.945 & 0.029 & 0.018 & 0.251 & 0.987 & 0.030 & 5.403 \\
\hline $\mathrm{NaClO}_{4}$ & 7.81 & 0.119 & 0.891 & 0.019 & 0.003 & 0.206 & 0.972 & 0.023 & 5.362 \\
\hline $\mathrm{Na}_{2} \mathrm{SO}_{4}$ & 1.80 & 0.149 & 0.808 & 0.047 & 0.001 & 0.115 & 0.959 & 0.027 & 4.796 \\
\hline $\mathrm{NaH}_{2} \mathrm{PO}_{4}$ & 108.69 & 0.049 & 0.942 & 0.002 & 0.236 & 0.366 & 0.959 & 0.073 & 7.597 \\
\hline $\mathrm{NaOH}$ & 25.32 & 0.089 & 0.873 & 0.010 & 0.105 & 0.323 & 0.971 & 0.023 & 6.094 \\
\hline $\mathrm{Na}_{2} \mathrm{CO}_{3}$ & 17.33 & 0.084 & 0.980 & 0.029 & 0.107 & 0.331 & 0.985 & 0.038 & 6.239 \\
\hline $\mathrm{NaHCO}_{3}$ & 588.24 & 0.012 & 0.989 & 0.002 & 1.542 & 0.530 & 0.997 & 0.012 & 11.141 \\
\hline
\end{tabular}



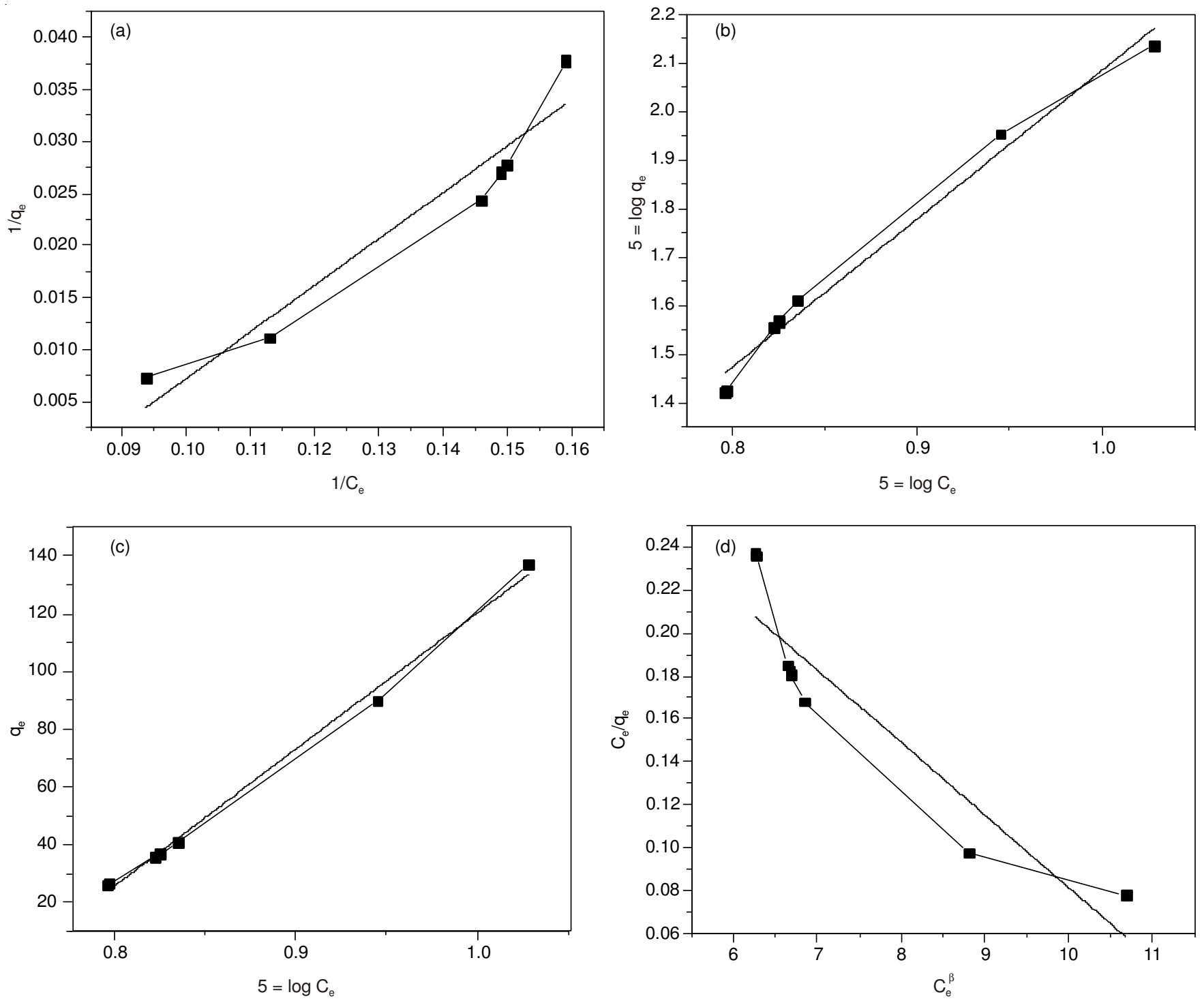

Fig. 3. Sorption isotherms of $\mathrm{NaCl}$ at low concentrations $\left(10^{-1}-10^{-8} \mathrm{M}\right.$ ) (a) Langmuir, (b) Freundlich (c) Temkin, (d) Redlich-Peterson

$$
\mathrm{R}_{\mathrm{L}}=\frac{1}{1+\mathrm{K}_{\mathrm{L}} \mathrm{C}_{0}}
$$

For the sorption process of sodium salts on PANIPI, the separation factor $\left(\mathrm{R}_{\mathrm{L}}\right)$, a dimensionless constant is less than one. This value fulfills the Langmuir isotherm condition of $0<\mathrm{R}_{\mathrm{L}}<1$ for a favourable sorption process. Hence, homogenous distribution of active binding sites on the PANIPI surface for the sodium salts, resulting in monolayer chemisorption of anions is envisaged. The maximum amount adsorbed per unit gram $\left(\mathrm{q}_{\mathrm{m}}\right)$ depend upon the size of different anions (Fig. 4) of sodium salts.

Thermodynamic studies: The thermodynamic parameter, Gibbs free energy of adsorption $\left(\Delta \mathrm{G}^{\circ}\right)$ of sodium salts on PANIPI is calculated from Langmuir constant ' $\mathrm{K}_{\mathrm{L}}$ ' related to the energy of adsorption as in eqn (3).

$$
\Delta \mathrm{G}^{\circ}=-\mathrm{RT} \ln (\mathrm{K})
$$

where $\Delta \mathrm{G}^{\circ}$ is the free energy change in $\mathrm{KJ} / \mathrm{mol}, \mathrm{R}$ is the universal gas constant with the value $8.314 / 1000 \mathrm{KJ}$ mol/K, T is the absolute temperature in Kelvin and $\mathrm{K}$ is the reciprocal of Langmuir constant $\mathrm{K}_{\mathrm{L}}$. These negative values (Table-2) of
$\Delta \mathrm{G}^{\circ}$ predicts the feasibility and spontaneity of sorption process which is also confirmed by isothermal modeling of equilibrium data and $\mathrm{q}_{\mathrm{m}}$ values ${ }^{5,6,25}$.

Freundlich isotherm: The sorption data are further fitted to Freundlich adsorption isotherm ${ }^{26}$ (Fig. 3b), describing the sorption equilibrium for both monolayer and multilayer adsorption. It assumes that as the sorbate concentration increases, the concentration of sorbate at the sorbent surface also increases exponentially. A linear form of this isotherm is expressed as in eqn. 4 ,

$$
\log \mathrm{q}_{\mathrm{e}}=\log \mathrm{K}_{\mathrm{F}}+\frac{1}{\mathrm{n}} \log \mathrm{C}_{\mathrm{e}}
$$

Freundlich isotherm constants $\mathrm{K}_{\mathrm{F}}$ and $\mathrm{n}$ incorporate all the factors affecting the sorption process such as sorption capacity $\left(\mathrm{K}_{\mathrm{F}}\right)$ and intensity of sorption $(\mathrm{n})$. From the slope and intercept of the Freundlich plot $n$ and $K_{F}$ are calculated and presented in Table- 2 . The $\mathrm{n}$ values obtained from this study fulfill Freundlich isotherm condition ${ }^{27}$ of $0<\mathrm{n}<1$ for sorption of all sodium salts showing favourability of sorption. It is evident from the values of $\mathrm{K}_{\mathrm{F}}$ and $\mathrm{n}$, that the sodium salts follow 

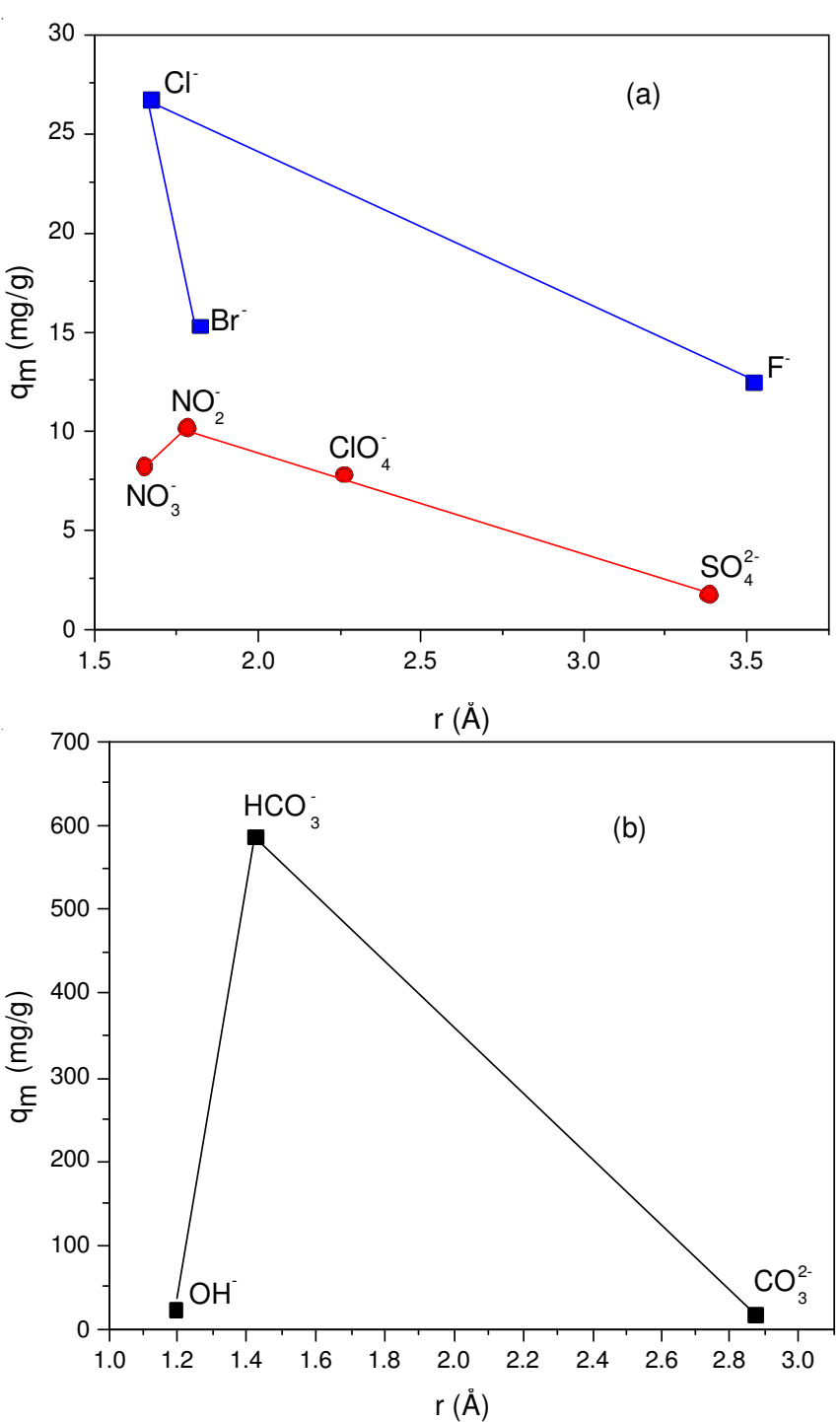

Fig. 4. Maximum amount adsorbed $\left(\mathrm{q}_{\mathrm{m}}\right) v s$. anionic radii

the order almost similar to that followed by $\mathrm{q}_{\mathrm{m}}$ values. It may be concluded that both Langmuir and Freundlich sorption isotherms simultaneously operate on the surface of PANIPI during the removal of anions from aqueous solutions of sodium salts.

Temkin isotherm: The Temkin ${ }^{28}$ isotherm (eqn. 5) assumes that the heat of adsorption of all the molecules on the adsorbent decreases linearly with coverage due to adsorbent-adsorbate interactions and that the adsorption is characterized by a uniform distribution of the bonding energies, up to some maximum binding energy ${ }^{29}$.

$$
\mathrm{q}_{\mathrm{e}}=\frac{\mathrm{RT}}{\mathrm{b}_{\mathrm{T}}} \ln \mathrm{K}_{\mathrm{T}}+\frac{\mathrm{RT}}{\mathrm{b}_{\mathrm{T}}} \ln \mathrm{C}_{\mathrm{e}}
$$

$\mathrm{K}_{\mathrm{T}}$ is the equilibrium binding constant $(\mathrm{L} / \mathrm{mg})$ and $\mathrm{b}_{\mathrm{T}}$ is the Temkin constant related to energy of adsorption $(\mathrm{KJ} / \mathrm{mol})$ which are calculated from the slope and intercept of the plot $\mathrm{q}_{\mathrm{e}}$ vs. $\log \mathrm{C}_{\mathrm{e}}$ (Fig. 3c). Temkin isotherm assumes that the fall in heat of adsorption is linear rather than logarithmic as stated in Freundlich expression and the heat of sorption of all the molecules in the layer would decrease linearly with coverage due to sorbate-sorbent interactions.

Redlich-Peterson isotherm: Redlich-Peterson isotherm ${ }^{30}$ is used as a compromise between Langmuir and Freundlich models. The linear form of this equation is given below

$$
\frac{\mathrm{C}_{\mathrm{e}}}{\mathrm{q}_{\mathrm{e}}}=\frac{1}{\mathrm{~K}_{\mathrm{RP}}}+\frac{\alpha_{\mathrm{RP}}}{\mathrm{K}_{\mathrm{RP}}} \mathrm{C}_{\mathrm{e}}^{\beta}
$$

where $K_{R P}, \alpha_{R P}$ and $\beta$ are Redlich constants. These constants can be predicted from the plot between $\mathrm{C}_{\mathrm{e}} / \mathrm{q}_{\mathrm{e}}$ versus $\mathrm{C}_{\mathrm{e}}{ }^{\beta}$ (Fig. 3d). In order to relate the three unknown parameters $K_{R P}$, $\alpha_{\mathrm{RP}}$ and $\beta$ a minimization procedure is adopted to maximize the coefficient of determination $\mathrm{R}^{2}$. However, the low value of $\mathrm{R}^{2}$ (Table-3) indicate that this model is not suitable for the sodium salt exchange on PANIPI.

The ion exchange capacity (IEC) and separation factor $(\alpha)$ calculated from eqns. 7 and 8 varies between 1.96-3.49 and 0.71-3.88 respectively (Table-4) for the ion exchange of sodium salts on PANIPI. These values are in the range expected for a good ion exchanger ${ }^{31,32}$.

$$
\mathrm{ICE}=\frac{\mathrm{C}_{0}-\mathrm{C}_{\mathrm{e}}}{\mathrm{w}} \mathrm{V}(\mathrm{meq} / \mathrm{g})
$$

$$
\alpha=\frac{\text { Concentration of ions in the resin phase }}{\text { Concentration of ions in the solution phase }}
$$

Based on all these results, the relative order of sorption of different sodium salts on PANIPI resin is given below

\begin{tabular}{|c|c|c|c|c|c|c|c|c|}
\hline \multicolumn{9}{|c|}{$\begin{array}{c}\text { TABLE-3 } \\
\text { ISOTHERMAL PARAMETERS OF TEMKIN AND REDLICH-PETERSON SORPTION ISOTHERMS FOR PANIPI ADSORBENT }\end{array}$} \\
\hline \multirow{2}{*}{$\mathrm{NaX}$} & \multicolumn{2}{|c|}{ Temkin constants } & \multirow{2}{*}{$\mathrm{R}^{2}$} & \multirow{2}{*}{ S.D } & \multicolumn{2}{|c|}{ Redlich Peterson constants } & \multirow{2}{*}{$\mathrm{R}^{2}$} & \multirow{2}{*}{ S.D } \\
\hline & $\mathrm{K}_{\mathrm{T}}(\mathrm{L} / \mathrm{mg})$ & $\mathrm{b}_{\mathrm{T}} \times 10^{-2}(\mathrm{KJ} / \mathrm{mol})$ & & & $\mathrm{K}_{\mathrm{RP}}(\mathrm{L} / \mathrm{mg})$ & $\alpha_{\mathrm{RP}}$ & & \\
\hline $\mathrm{NaF}$ & 5.190 & 1.638 & 0.953 & 0.044 & 1.445 & 0.016 & 0.871 & 0.054 \\
\hline $\mathrm{NaCl}$ & 5.562 & 1.228 & 0.995 & 0.083 & 2.386 & 0.084 & 0.826 & 0.057 \\
\hline $\mathrm{NaBr}$ & 5.449 & 1.365 & 0.996 & 0.051 & 1.626 & 0.099 & 0.874 & 0.056 \\
\hline $\mathrm{NaNO}_{2}$ & 4.315 & 3.021 & 0.843 & 0.066 & 1.145 & 0.116 & 0.954 & 0.092 \\
\hline $\mathrm{NaNO}_{3}$ & 4.819 & 2.061 & 0.871 & 0.072 & 1.039 & 0.114 & 0.895 & 0.128 \\
\hline $\mathrm{NaClO}_{4}$ & 5.335 & 1.498 & 0.998 & 0.047 & 0.969 & 0.121 & 0.839 & 0.096 \\
\hline $\mathrm{Na}_{2} \mathrm{SO}_{4}$ & 5.308 & 1.469 & 0.994 & 0.064 & 0.279 & 0.148 & 0.778 & 0.245 \\
\hline $\mathrm{NaH}_{2} \mathrm{PO}_{4}$ & 2.996 & 3.283 & 0.855 & 0.111 & 3.282 & 0.078 & 0.969 & 0.012 \\
\hline $\mathrm{NaOH}$ & 5.579 & 1.254 & 0.995 & 0.073 & 2.422 & 0.084 & 0.767 & 0.053 \\
\hline $\mathrm{Na}_{2} \mathrm{CO}_{3}$ & 4.582 & 1.556 & 0.964 & 0.126 & 1.579 & 0.082 & 0.876 & 0.121 \\
\hline $\mathrm{NaHCO}_{3}$ & 6.513 & 0.896 & 0.995 & 0.064 & 6.935 & 0.110 & 0.947 & 0.010 \\
\hline
\end{tabular}

$$
\begin{gathered}
\mathrm{HCO}_{3}^{-}>\mathrm{H}_{2} \mathrm{PO}_{4}^{-}>\mathrm{Cl}^{-}>\mathrm{CO}_{3}^{2-}>\mathrm{OH}^{-}> \\
\mathrm{Br}^{-}>\mathrm{F}^{-}>\mathrm{NO}_{2}^{-}>\mathrm{NO}_{3}^{-}>\mathrm{ClO}_{4}^{-}>\mathrm{SO}_{4}^{2-}
\end{gathered}
$$

The observed relative order may be explained on the basis of ionic radii and hydration energies of the anions. The plot of 


\begin{tabular}{lcccc}
\hline \multicolumn{5}{c}{ TABLE-4 } \\
\multicolumn{5}{c}{ ION EXCHANGE CHARACTERISTICS OF } \\
\hline \multicolumn{5}{c}{ PANIPI WITH SODIUM SALTS } \\
\hline $\mathrm{NaX}$ & ${ }^{\mathrm{a}} \mathrm{K}_{\mathrm{PI}^{-}}$ & ${ }^{-} \alpha$ & $\begin{array}{c}\text { IEC } \\
(\mathrm{meq} / \mathrm{g})\end{array}$ & $\begin{array}{c}\text { Anionic } \\
\text { radius } \mathrm{r}(\AA)\end{array}$ \\
\hline $\mathrm{NaF}$ & $7.94 \times 10^{-9}$ & 0.91 & 2.00 & ${ }^{\mathrm{b}} 3.52$ \\
$\mathrm{NaCl}$ & $5.62 \times 10^{-8}$ & 0.74 & 2.71 & 1.67 \\
$\mathrm{NaBr}$ & $6.31 \times 10^{-5}$ & 0.22 & 2.23 & 1.82 \\
$\mathrm{NaNO}_{2}$ & $6.31 \times 10^{-7}$ & 1.30 & 2.99 & 1.78 \\
$\mathrm{NaNO}_{3}$ & $3.16 \times 10^{-4}$ & 1.59 & 2.01 & 1.65 \\
$\mathrm{NaClO}_{4}$ & $5.62 \times 10^{-6}$ & 1.10 & 2.12 & 2.21 \\
$\mathrm{Na}_{2} \mathrm{SO}_{4}$ & $1.38 \times 10^{-7}$ & 0.24 & 1.96 & 3.38 \\
$\mathrm{NaH}_{2} \mathrm{PO}_{4}$ & $4.37 \times 10^{-4}$ & 3.88 & 2.25 & - \\
$\mathrm{NaOH}^{1}$ & $1.41 \times 10^{-12}$ & 0.94 & 2.48 & 1.19 \\
$\mathrm{Na}_{2} \mathrm{CO}_{3}$ & $3.98 \times 10^{-13}$ & 2.07 & 3.01 & 2.87 \\
$\mathrm{NaHCO}_{3}$ & $6.92 \times 10^{-9}$ & 0.71 & 3.49 & 1.42 \\
\hline${ }^{\mathrm{a}}\left[\mathrm{NaX}_{=}=2 \mathrm{M}\right.$, ${ }^{b}$ hydrated radius.
\end{tabular}

$\mathrm{q}_{\mathrm{m}}$ vs. anionic radii (Fig. 4) reveals that only anions of certain radii lying between $1.4-1.8 \AA$ can bind strongly to the PANI resin. Among the sodium halides (Fig. 4a), $\mathrm{NaCl}$ exchanges readily even though its anionic radius $\left(\mathrm{Cl}^{-}=1.67 \AA\right)$ lies between $\mathrm{NaF}$ and $\mathrm{NaBr}$. When bases are considered ion with a radius of $1.42 \AA$ and $\Delta \mathrm{G}_{\mathrm{h}}$ of $-335 \mathrm{KJ} / \mathrm{mol}$ is found to have the highest adsorption capacity (Fig. 4b). Among the other sodium salts, $\mathrm{NaNO}_{2}$ has the highest $\mathrm{q}_{\mathrm{m}}$ value. $\mathrm{SO}_{4}^{2-}$ ion with the largest radius of $3.38 \AA$ and $\Delta \mathrm{G}_{\mathrm{h}}$ of $-1295 \mathrm{KJ} / \mathrm{mol}$ has the least adsorption capacity.

Ion exchange is dependent on ionization of electrolyte in solution, but the present study shows that factors other than simple ionization can be the deciding factors for the exchange to occur. The water structure involvement must be considered before an observed trend in anion selectivity is to be explained. At PANIPI/water interface the water structure breaks down. Such behaviour is maximized by ion-water and water-water interaction in the total system. It can be further said that the differences in ion-water (ion hydration) and water-water (water structure) interaction between the resin and the solvent phase are the principle origins of anion exchange selectivity when synthetic organic exchangers are involved.

In general, large ions prefer the external solution as compared to the resin phase. The sulphate ions with the largest radii and maximum hydration energy tend to remain in the solution. Since hydration of ions are inversely related with the ionic radii, the smallest fluoride ion has the strongest interaction with water and exist as hydrated ion. The radius of the hydrated fluoride ion being large remains in the solution like the sulphate ion. The exchange of this hydrated species is found to be the least among the sodium halides (Fig. 4a).

Sorption at high concentration: Generally sorption process should be complete at high concentration of sorbate. In order to explore this phenomenon, sorption process is attempted at a high salt concentration $(2 \mathrm{M})$. At this concentration, the $\mathrm{pH}$ of the sodium salt solutions changed dramatically with a rapid fall in $\mathrm{pH}$ (Fig. 5a). The sorption process is accompanied by the release of picric acid followed by the entry of sodium salts as ion-pairs (Scheme-IIIb).

When high concentration of bases $\mathrm{NaOH}, \mathrm{Na}_{2} \mathrm{CO}_{3}$ and $\mathrm{NaHCO}_{3}$ are used, an increase in $\mathrm{pH}$ from 8-13 (Fig. 5b-d) is observed. Hence, besides the sorption process, dedoping and complex formation ${ }^{33,34}$ (Scheme-IIIc) may compete. The $\mathrm{K}_{\mathrm{PI}^{-}}^{\mathrm{X}^{-}}$ values determined from the midpoints of the $\mathrm{pH}$ variation curves are presented in Table-4. It is interesting to note that the equilibrium constant for the above sorption process for all the sodium salts are lower $\left(\mathrm{K}_{\mathrm{F}}=10^{-4}-10^{-13}\right)$ compared to the Freundlich constant at low concentrations $\left(10^{-1}-10^{-3}\right)$. The sorption percentage obtained from eqn (9) at an adsorbent dose of $1 \mathrm{mg}$ of PANPI resin in sodium salt solutions is $80-100 \%$ whereas it has decreased to $70 \%$ for $10 \mathrm{mg}$ of resin in $2 \mathrm{M}$ solutions. Further, the $\alpha$ values determined at this concentration do not correlate with the $\mathrm{q}_{\mathrm{m}}$ values obtained at low concentrations. This may be due to the changes in conformation of PANIPI at different salt concentrations.

$$
\text { Sorption percentage }=\frac{\mathrm{C}_{0}-\mathrm{C}_{\mathrm{e}}}{\mathrm{C}_{0}} \times 100
$$

Sorption mechanism: Based on the above results a tentative mechanism has been proposed for the sorption process. The presence of picrate ion on the surface renders hydrophilicity to PANIPI resin and the ions are attracted towards the PANI surface. The anions bind to the imine sites and the hydrogen atoms on the NH groups, while the sodium ions move towards the picrate ions released into the solution. This phenomenon causes changes in the stretching frequencies of the $\mathrm{NH}$ group at $3200 \mathrm{~cm}^{-1}$ and also affects the $\mathrm{C}-\mathrm{N}-\mathrm{C}$ bending vibrations. The sorption of ions initially occurs as a monolayer. Multilayer formation on PANI surface may take place subsequently due to ion pairing. At high concentrations, in the presence of excess sodium salts picric acid is released as in Scheme-IIIb. The sodium ions move towards the lone pairs present on the secondary NH sites as ion pairs, releasing picric acid from the imine sites and enhancing more benzenoid forms than quinonoid forms (Table-5) in the PANI chain. When bases are used the $\mathrm{pH}$ of the solution increases upto 13. Bases are known to dedope emeraldine salt form to emeraldine base form. When excess of bases are present besides dedoping of the PANIPI, (Scheme-IIIc) the released picric acid is converted to sodium picrate and further, formation of picrate complexes ${ }^{33,34}$ may take place (Fig. $1 b, \lambda_{\max }=400-420 \mathrm{~nm}$ ).

\begin{tabular}{|c|c|c|c|c|}
\hline \multicolumn{5}{|c|}{$\begin{array}{c}\text { TABLE-5 } \\
\text { UV-VISIBLE SPECTRAL RESULTS BEFORE AND } \\
\text { AFTER EXCHANGE OF PANIPI RESIN IN DMF }\end{array}$} \\
\hline \multirow{2}{*}{$\mathrm{NaX}$} & \multicolumn{2}{|c|}{$\lambda_{\max }(\mathrm{nm})$} & \multirow{2}{*}{$\mathrm{y}$} & \multirow{2}{*}{${ }^{\mathrm{a}} 1-\mathrm{y}$} \\
\hline & Benzenoid (B) & Quinonoid (Q) & & \\
\hline - & 360 & 621 & 0.70 & 0.30 \\
\hline $\mathrm{NaF}$ & 349 & 610 & 0.52 & 0.48 \\
\hline $\mathrm{NaCl}$ & 378 & 577 & 0.91 & 0.09 \\
\hline $\mathrm{NaBr}$ & 377 & 568 & 0.92 & 0.08 \\
\hline $\mathrm{NaNO}_{2}$ & 373 & 610 & 0.60 & 0.40 \\
\hline $\mathrm{NaNO}_{3}$ & 353 & 626 & 0.53 & 0.47 \\
\hline $\mathrm{NaClO}_{4}$ & 350 & 626 & 0.53 & 0.47 \\
\hline $\mathrm{Na}_{2} \mathrm{SO}_{4}$ & 370 & 601 & 0.78 & 0.22 \\
\hline $\mathrm{NaH}_{2} \mathrm{PO}_{4}$ & 361 & 627 & 0.58 & 0.42 \\
\hline $\mathrm{NaOH}$ & 327 & 605 & 0.71 & 0.29 \\
\hline $\mathrm{Na}_{2} \mathrm{CO}_{3}$ & 332 & 610 & 0.74 & 0.26 \\
\hline $\mathrm{NaHCO}_{3}$ & 376 & 609 & 0.77 & 0.23 \\
\hline$y=\frac{O D}{O D}$ & & & & \\
\hline
\end{tabular}



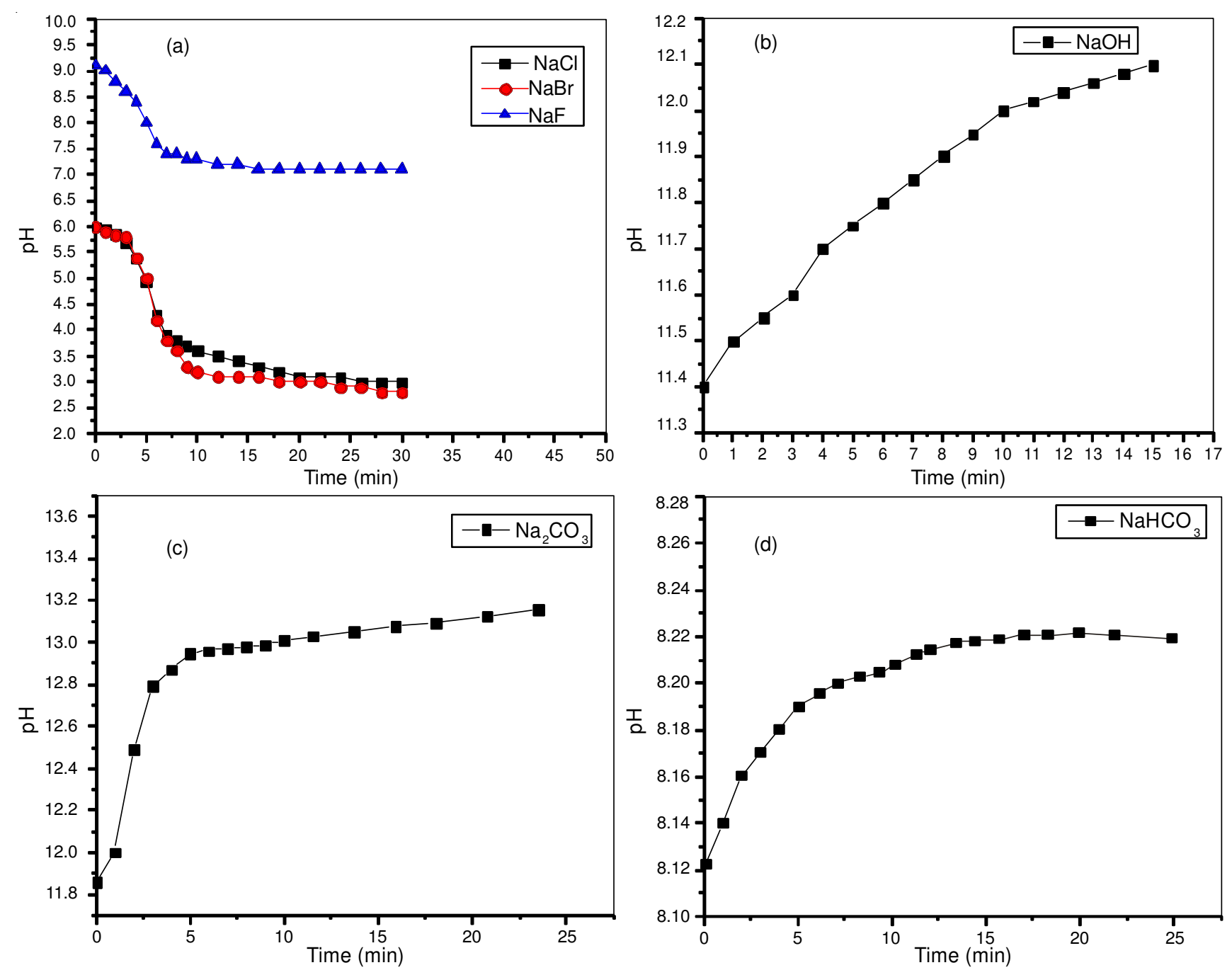

Fig. 5. Variation of $\mathrm{pH}$ with time at high concentrations (2 M)

\section{Structural characterization after sorption:}

UV-visible spectra: From the UV-visible spectral data, the structure of PANIPI contains $70 \%$ benzenoid and $30 \%$ quinonoid forms (Table-5). Sorption of ions lead to the changes in the percentage of quinonoid and benzenoid forms depending on the type of anions present in the sodium salt (Table-5). Sorption of salts such as $\mathrm{NaCl}$ and $\mathrm{NaBr}$ produce higher percentage of benzenoid forms compared to PANIPI. Among the sodium salts $\mathrm{Na}_{2} \mathrm{SO}_{4}$ does not alter this percentage found in PANPI. Sodium sulfate being the least in the sorption capacity does not alter resin structure whereas all the other sodium salts interact strongly with the resin producing almost $50 \%$ benzenoid and quinonoid forms. When bases are used, the percentages of benzenoid and quinonoid forms calculated from optical density measurements is similar to PANIPI eventhough dedoping to EB form is expected. This may be due to the absorption of picrate complexes merging with the absorptions of benzenoid forms of PANPI.

FT-IR spectra: The changes in the IR spectral bands of PANIPI after sorption confirms anion exchange behaviour. The peak at $3246 \mathrm{~cm}^{-1}$, due to $\mathrm{N}-\mathrm{H}$ stretching vibration in PANIPI is anion sensitive. This vibration is blue shifted after the sorption process (Table-1). The series of stretching vibration patterns

\begin{tabular}{|c|c|c|c|c|}
\hline \multicolumn{5}{|c|}{$\begin{array}{c}\text { TABLE-6 } \\
\text { ANTIBACTERIAL AND ANTIFUNGAL } \\
\text { ACTIVITIES OF PANIPI IN DMSO }\end{array}$} \\
\hline \multirow[b]{2}{*}{ Strains } & \multicolumn{4}{|c|}{ Zone of inhibition (mm) } \\
\hline & $\begin{array}{c}25 \\
(\mu \mathrm{g} / \mathrm{mL})\end{array}$ & $\begin{array}{c}50 \\
(\mu \mathrm{g} / \mathrm{mL})\end{array}$ & $\begin{array}{c}75 \\
(\mu \mathrm{g} / \mathrm{mL}) \\
\end{array}$ & $\begin{array}{c}100 \\
(\mu \mathrm{g} / \mathrm{mL})\end{array}$ \\
\hline Shigella dysenteriae & 14 & 15 & 17 & 19 \\
\hline Salmonella enterica & 10 & 13 & 17 & 19 \\
\hline Klebsiella pпеитопiа & 10 & 13 & 15 & 17 \\
\hline Escherichia coli & - & 14 & 15 & 18 \\
\hline Pseudomonas aeruginosa & - & 10 & 11 & 14 \\
\hline Staphylococcus auerus & 13 & 14 & 15 & 17 \\
\hline Streptococcus pyogenes & - & 12 & 14 & 17 \\
\hline Bacillus subtilis & - & 12 & 13 & 14 \\
\hline Enterococcus faecalis & - & 11 & 12 & 13 \\
\hline Candida albicans & 10 & 13 & 14 & 17 \\
\hline
\end{tabular}

at $3010-2900 \mathrm{~cm}^{-1}$ are also affected. The band features around $2800-2400 \mathrm{~cm}^{-1}$ confirms the presence of ES structure. Quinonoid and benzenoid ring vibrations at $1588,1491 \mathrm{~cm}^{-1}$ are not much affected. The presence of anions on PANI backbone is confirmed by the anion stretching vibrations (Table-1). The stretching vibration around $1300 \mathrm{~cm}^{-1}$, characteristic of ES structure are slightly shifted. When bases are used in ionexchange, the resin obtained exhibit a red shift upto $50 \mathrm{~cm}^{-1}$ 
and a shift of $1137 \mathrm{~cm}^{-1}$ band to $1160 \mathrm{~cm}^{-1}$ confirming the presence of picrate complexes. This may be corroborated by the presence of weak anion sensitive band occurring as a shoulder at $3200 \mathrm{~cm}^{-1}$.

Desorption studies: Desorption studies carried out by the column experiment using $\mathrm{Na}_{2} \mathrm{CO}_{3}(0.1 \mathrm{M})$ showed that $96 \%$ desorption occurred initially. Sodium carbonate is selected as an eluent for the column experiment due to its high $\alpha$-value (Table-4). It is evident from the elution curves (Fig. 6) that the resin can be redoped readily confirming the reversible nature of the sorption-desorption equilibrium. Subsequent cycles of sorption and desorption operations resulted in an average of 95-96\% exchange capacity. These experiments clearly depict that PANIPI resin can be regenerated and sodium salt solutions can be readily recycled on the resin column.

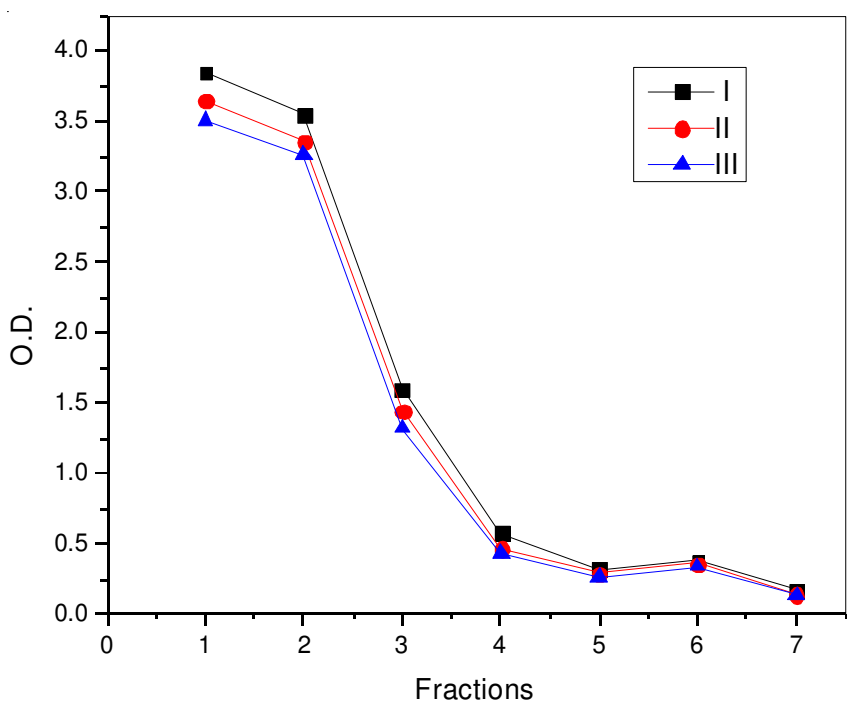

Fig. 6. Desorption curves from column experiments

Antibacterial and antifungal activities: It is reported that PANI salts ${ }^{35-38}$ and picrate complexes ${ }^{39}$ are effective as microbial inhibitors. Hence antibacterial studies are performed on PANIPI which has a good sorption potential. The zone of inhibition (Fig. 7) produced by PANIPI on several bacterial strains (Table-6) indicate its effectiveness as a potent antibacterial agent against both Gram-negative and Gram-positive bacteria. Further it is also effective against the fungus Candida albicans.

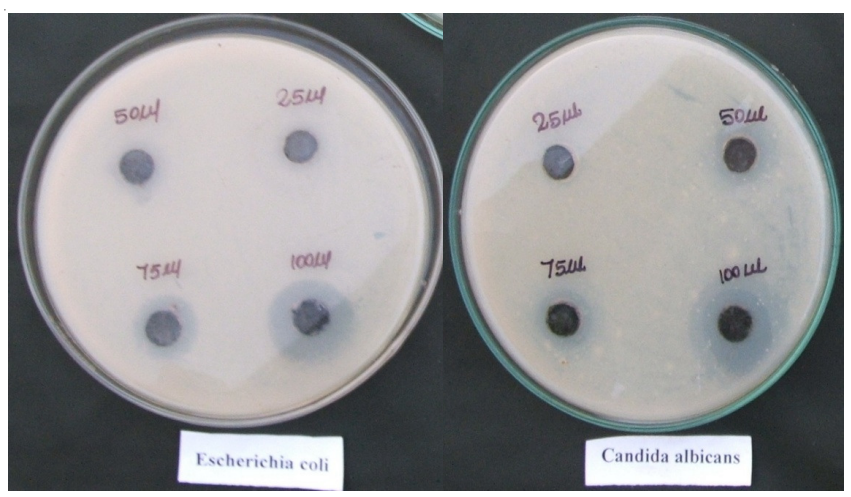

Fig. 7. Antibacterial and anifungal activities of PANIPI

\section{Conclusion}

It is clear from these studies that the pristine PANIPI removes anions from aqueous solutions at a relatively low adsorbent dose and low contact time. Batch studies showed that $80-100 \%$ of anions are removed from aqueous solutions by PANIPI. This efficiency may be due to the small size of the PANIPI resulting in large surface area for ion exchange. Since Langmuir, Freundlich and Temkin isotherms are followed, it may be concluded that both monolayer and multilayer adsorptions occur simultaneously on the surface of PANIPI. Langmuir adsorption capacity and free energy of adsorption indicate that adsorption is favourable and endothermic. Ions of only certain radii 1.4-1.8 A selectively undergo effective exchange, while large ions exhibit the least sorption capacity. These results imply that PANIPI is suitable for adsorbing sodium salts with anion exchanging mechanism. The ion exchange capacity and $\alpha$ values are within the limits expected for a good ion exchanger. The dopant picric acid and eluted picrate ions are chromogenic making PANIPI, a superior adsorbent and an ion exchanging material compared to conventional ion exchangers. The added advantage of PANIPI is that it also possesses both antibacterial and antifungal activities. Hence, this novel material can be used in desalination, ion detection and water softening processes.

\section{ACKNOWLEDGEMENTS}

The authors thank UGC for the minor project, ACIC of St. Joseph's College, Tiruchirappalli for FT-IR spectra, CISL of Annamalai University for the SEM image and Eumic Analytical Lab for the antimicrobial studies. The authors are grateful to the Management, Seethalakshmi Ramaswami College for the research facilites.

\section{REFERENCES}

1. A.K. De, Environmental Chemistry, New Age International Publishers, New Delhi, India, edn 5, p. 10 (2003).

2. V.J. Ingelzakis and S.G. Poulopoulos, Adsorption, Ion Exchange and Catalysis-Design of Operations and Environmental Applications, Elsevier Science, Oxford, UK, edn 1, p. 264 (2006).

3. R. Ansari, Acta Chim. Slov., 53, 88 (2006).

4. F. Kanwal, R. Rehman, J. Anwar and T. Mahmud, EJEAFChe, 10, 2972 (2011).

5. M. Ghorbani, H. Eisazadeh and A.A. Ghoreyshi, Iranica J. Energy Environ., 3, 66 (2012).

6. F. Kanwal, R. Rehman, J. Anwar and M. Saeed, Asian J. Chem., 25, 2399 (2013).

7. E. Subramanian and R.D. Ramalakshmi, J. Sci. Ind. Res. (India), 69, 621 (2010).

8. R. Ansari and Z. Mosayebzadeh, Iranian Polym. J., 19, 541 (2010).

9. R. Ansari, Z. Mosayebzadeh and M.B. Keivani, J. Adv. Sci. Res., 2,27 (2011).

10. R. Ansari and H. Dezhampanah, Eur. Chem. Bull., 2, 220 (2013).

11. S. Tan, A. Laforgue and D. Belanger, Langmuir, 19, 744 (2003).

12. J. Wang, Synth. Met., 132, 49 (2002).

13. A. Parsa, S.M. Hosseini and M. Asefoddoleh, Eur. J. Sci. Res., 26, 369 (2009).

14. C. Dhivya, S.A.A. Vandarkuzhali, R. Santhi and N. Radha, Indian J. Appl. Res, 6, 62 (2013).

15. C. Perez, M. Paul and P. Bezique, Alta Biomed. Group Exper., 15, 113 (1990).

16. D.C. Sindhimeshram and M.C. Gupta, Indian J. Chem., 34A, 260 (1995).

17. A.B. Samui, A.S. Patankar, R.S. Satpute and P.C. Deb, Synth. Met., 125, 423 (2001).

18. B.C. Roy, M.D. Gupta, L. Bhoumik and J.K. Ray, Synth. Met., 130, 27 (2002). 
19. A.G. MacDiarmid, A.J. Epstein, P.N. Prasad and J.K. Nigam, Frontiers of Polymer Research, Plenum Press, New York, p. 259 (1991).

20. M. Wan and J. Yang, J. Appl. Polym. Sci., 55, 399 (1995).

21. R.K. Paul and C.K.S. Pillai, Synth. Met., 114, 27 (2000).

22. J.P. Pouget, M.E. Jozefowicz, A.J. Epstein, X. Tang and A.G. MacDiarmid, Macromoleucles, 24, 779 (1991).

23. I. Langmuir, J. Am. Chem. Soc., 40, 1361 (1918).

24. M.B. Krishna and P. Venkateswarlu, Indian J. Chem. Technol., 18, 381 (2011).

25. N.A. Oladoja, I.O. Asia, C.O. Aboluwoye and Y.B. Oladimeji, Turk. J. Eng. Environ. Sci., 32, 303 (2008).

26. H.Z. Freundlich, J. Phys. Chem., 57A, 385 (1906).

27. K.B. Nagashanmugam and K. Srinivasan, Indian J. Chem. Technol., 18, 391 (2011).

28. M.J. Temkin and V. Pyzhev, Acta Physiochim. URS., 12, 217 (1940).

29. Sh.S. Kalagh, H. Babazadeh, A.H. Nazemi and M. Manshouri, Caspian J. Environ. Sci. (China), 9, 243 (2011).

30. O. Redlich and D.L. Peterson, J. Phys. Chem., 63, 1024 (1959).
31. C.R. Indulal, A.V. Vaidyan, G.S. Kumar and R. Raveendran, Indian J. Chem. Technol., 18, 488 (2011).

32. R.B. Kaner, Synth. Met., 125, 65 (2001).

33. M.R. Crampton and V. Gold, J. Chem. Soc. B, 893 (1966).

34. N. Radha, S.D. Begum and J.S. Mary, Indian J. Chem., 26A, 1006 (1987).

35. M.R.G. Nikolaidis, A.J. Easteal S. Stepanovic, US patent 20100196306A1 (2010).

36. M.R. Gizdavic-Nikolaidis, J.R. Bennett, S. Swift, A.J. Easteal and M. Ambrose, Acta Biomater., 7, 4204 (2011).

37. K.P. Jotiram, R.G.S.V. Prasad, V.S. Jakka, R.S.L. Aparna and A.R. Phani, Nano Biomed. Eng., 4, 144 (2012).

38. R.G.S.V. Prasad, K.S.V. Chaitanya, M. Tejoram, D. Basavaraju, K.N. Rao, R.R. Kumar, S. Sreenivasan and A.R. Phani, J. Pharm. Res., 5, 370 (2012).

39. C. Mallikarjunaswamy, D.G. Bhadregowda and L. Mallesha, J. Chem., Article id 727182 (2013). 